Klinik für Reproduktionsmedizin

Departement für Nutztiere

der Vetsuisse-Fakultät Universität Zürich

Direktor: Prof. Dr. H. Bollwein

Arbeit unter Leitung von

Prof. D. Gerber, University of Pretoria,

Faculty of Veterinary Science, Section of Reproduction

\title{
Ex vivo influence of carbetocin on equine myometrial muscles and comparison with oxytocin
}

\author{
Inaugural-Dissertation \\ zur Erlangung der Doktorwürde der \\ Vetsuisse-Fakultät Universität Zürich \\ vorgelegt von \\ Daniela Steckler \\ Tierärztin \\ aus Kaiserlautern, Deutschland \\ genehmigt auf Antrag von \\ PD Dr. Fredi Janett, Referent
}

Zürich, 2012 


\title{
Ex vivo influence of carbetocin on equine myometrial muscles and comparison with oxytocin
}

\author{
D. Steckler ${ }^{\mathrm{a}, *}$, V. Naidoo ${ }^{\mathrm{b}}$, D. Gerber ${ }^{\mathrm{a}, \mathrm{c}}$, W. Kähn ${ }^{\mathrm{d}}$ \\ a Section of Reproduction, Faculty of Veterinary Science, Onderstepoort, South Africa \\ ${ }^{\mathrm{b}}$ University of Pretoria, Biomedical Research Centre (UPBRC) and Department of Paraclinical Sciences, Faculty of Veterinary Science, \\ Onderstepoort, South Africa \\ ${ }^{\mathrm{c}}$-Tech Pharmacy, Midrand, Gauteng, South Africa \\ ${ }^{\mathrm{d}}$ Klinik für Fortpflanzungsmedizin, Vetsuisse-Fakultät, University of Zürich, Zürich, Switzerland
}

Received 19 September 2011; received in revised form 9 February 2012; accepted 10 February 2012

\begin{abstract}
To determine the intercyclic effect of oxytocin and carbetocin on equine myometrial tissue, the effect of the drugs was evaluated through pharmacokinetic and pharmacodynamic studies. The complete pharmacokinetic profile for oxytocin was unknown and had to be established. To do so, 25 IU of oxytocin were administered intravenously to six cycling mares and blood samples were collected before and 2, 4, 8, and 15 min after administration. The half-life of oxytocin was determined to be 5.89 min, the clearance rate $11.67 \mathrm{~L} / \mathrm{min}$, mean residence time (MRT) $7.78 \mathrm{~min}$. The effective plasma concentration was estimated to be $0.25 \mathrm{ng} / \mathrm{mL}$. This was similar to the concentration achieved for the organ bath study where the concentration that produced $50 \%$ of the maximum effect $\left(\mathrm{EC}_{50}\right)$ was calculated at $0.45 \mathrm{ng} / \mathrm{mL}$. To determine the intercyclic effect of oxytocin and carbetocin uterine myometrial samples were collected from slaughtered mares in estrus, diestrus, and anestrus. The samples were mounted in organ baths and exposed to four ascending, cumulative doses of oxytocin and carbetocin. Area under the curve and amplitude, maximum response $\left(\mathrm{E}_{\max }\right)$, and concentration that produced $50 \%$ of the maximum effect were studied for each agonist and statistically evaluated. The effect of oxytocin on equine myometrial tissue was higher during diestrus, and surprisingly anestrus, than during estrus, whereas the effect of carbetocin was the same independent of the stage of estrous cycle. A significant difference was found for estrous and anestrous samples when oxytocin was used but not when carbetocin was used.
\end{abstract}

(C) 2012 Elsevier Inc. All rights reserved.

Keywords: Equine myometrium; Oxytocin; Carbetocin; Ex vivo; Organ bath

\section{Introduction}

Two major causes for economic losses in the equine breeding industry are the failure of a mare to conceive or a delay in a mare's reconception [1,2], both of which have shown to be caused mainly by a delayed uterine clearance in association with reduced uterine contrac-

\footnotetext{
* Corresponding author. Tel.: +27125298218; fax: +27125298314.

E-mail address: daniela-steckler@gmx.de (D. Steckler).
}

tility [2]. Uterine contractions are vital in the transport of sperm through the uterus to the uterotubal junction, as well as for the clearance of sperm after breeding, or of accumulated intrauterine fluids [3]. A large percentage of mares susceptible to endometritis most likely have intrinsic contractile defects in myometrial contractility [4]. This results in accumulation of intrauterine fluid after breeding, predisposing the mare to persistent mating-induced endometritis (PMIE) [4]. In the mare, treatment of PMIE and stimulation of postpartum uter- 
ine involution [5] includes the use of oxytocin and natural or synthetic prostaglandin $\mathrm{F}_{2 \alpha}\left(\mathrm{PGF}_{2 \alpha}\right)$, which aid in promoting uterine clearance. Oxytocin stimulates uterine contractions, release of arachidonic acid, and prostaglandin formation, which in turn enhance uterine contractions by causing membrane depolarization and by increasing the number of gap junctions [6]. Clearance of uterine contents provides a uterine environment suitable for an embryo descending into the uterus, thus improving conception rates.

Both oxytocin and $\mathrm{PGF}_{2 \alpha}$ have disadvantages in their application; for example, oxytocin needs to be given in short intervals because of its short half-life (6.8 $\mathrm{min})$, and $\mathrm{PGF}_{2 \alpha}$ in its natural form has unwanted side effects (sweating, tachypnea, increased gastrointestinal motility, signs of colic) [7,8]. A drug without side effects and a long half-life stimulating a prolonged tocolytic effect might improve uterine clearance. The use of carbetocin, a long acting analogue of oxytocin, has been investigated as a beneficial form of treatment on uterine involution in bovines [9], as well as in humans for the treatment of postpartum hemorrhage [10-12]. In adult, nonlactating anestrous mares carbetocin has been shown to have a half-life of approximately $17 \mathrm{~min}$, which is 2.5 -fold longer than that of oxytocin, and not associated with any side effects [7]. As such we believe that carbetocin may prove more beneficial in horses in inducing parturition, decreasing the time to conception postpartum, and aid in the treatment of PMIE [13].

For the current study we investigated if the concentration-dependent contractile responses of carbetocin in healthy estrous, diestrous, and anestrous equine myometrial smooth muscle were superior to that of oxytocin. The duration of effect was extrapolated from the pharmacokinetic time versus concentration profile for the mentioned oxytocin (self-generated) and carbetocin [7].

\section{Materials and methods}

\subsection{Pharmacokinetic study}

The pharmacokinetics of oxytocin was evaluated after a single intravenous dose in adult horses.

\subsubsection{Animals}

Six healthy, adult, nonlactating cycling Nooitgedacht mares of the Veterinary Faculty were used for the study. All animals were vaccinated and dewormed, and kept in their usual environment. The study was approved by the Animal Use and Care Committee of the University of Pretoria according the South African standard for the care of laboratory animals (SANS 10 386, Project Number V026/08).

\subsubsection{Sample collection and preparation}

An indwelling intravenous catheter was placed into the left jugular vein for blood sampling. The oxytocin treatment (25 IU) (Fentocin; Virbac, Centurion, South Africa) was administered into the opposite jugular vein by means of a disposable syringe and a 20-gauge needle. Blood samples were collected before administration and at 2, 4, 8, and 15 min after oxytocin administration, into chilled serum tubes containing aprotonin (500 kallikrein inhbitor unit (kIU)/mL of blood) (Aprotonin; Sigma-Aldrich (Pty), Ltd., Aston Manor, South Africa).

After collection, the blood samples were centrifuged at $1600 \times g$ at $4{ }^{\circ} \mathrm{C}$ for $15 \mathrm{~min}$ and the supernatant of each sample was transferred to a labeled polycarbonate tube and immediately frozen at $-80{ }^{\circ} \mathrm{C}$. Hormone assay samples were extracted using a $200 \mathrm{mg}$ C18 Sep-Pak (Waters Cooperation, Milford, MA, USA) column under the following conditions: equilibration of the column with $1 \mathrm{~mL}$ of acetonitrile, followed by 10 to $25 \mathrm{~mL}$ of $0.1 \%$ trifluoroacetic acid (TFA) in water before application of the sample. After sample application, the sample was washed with 10 to $20 \mathrm{~mL}$ of $0.1 \%$ TFA in water, followed by a final elution with $3 \mathrm{~mL}$ of acetonitrile $0.1 \%$ TFA in water (60:40). Samples were subsequently dried under a steady stream of nitrogen at $40{ }^{\circ} \mathrm{C}$.

Oxytocin concentrations were quantified using the oxytocin Enzyme Immunoassay Kit (Assay Designs, Ann Arbor, MI, USA) according to the manufacturer's instructions. In short, $100 \mu \mathrm{L}$ of sample were pipetted into sample wells with $50 \mu \mathrm{L}$ of both the blue conjugate (alkaline phosphatase conjugated with oxytocin) and antibody. The plates were subsequently gently mixed and incubated at $4{ }^{\circ} \mathrm{C}$ for 18 to $24 \mathrm{~h}$. After three washes with $400 \mu \mathrm{L}$ of wash solution $5 \mu \mathrm{L}$ of blue conjugate was added into to wells with $200 \mu \mathrm{L}$ of p-nitrophenylphosphate in buffer (pNpp Substrate, Assay Designs, Ann Arbor, MI, USA) and allowed to incubate at room temperature for $1 \mathrm{~h}$ before the addition of $50 \mu \mathrm{L}$ of Stop Solution. The 96-well plate was immediately read with an Eliza iEMS reader MF (Labsystems, Helsinki, Finland; wavelength range 340 to $850 \mathrm{~nm}$, wavelength accuracy \pm $2 \mathrm{~nm}$ ) at an optical density of $405 \mathrm{~nm}$ with correction between 570 and $590 \mathrm{~nm}$.

\subsubsection{Pharmacokinetic analysis}

Noncompartmental pharmacokinetic analysis was performed using Kinetica Version 5.0 (Thermo Fisher 
Scientific, BioImage, Soeborg, Denmark). The area under the concentration-time curve to the last plasma sampling time $\left(\mathrm{AUC}_{\text {last }}\right)$ was calculated according to the linear trapezoidal rule. The area under the concentration-time curve extrapolated to infinity $\left(\mathrm{AUC}_{\mathrm{inf}}\right)$ as $\mathrm{AUC}_{\text {inf }}+\mathrm{Ct} / \mathrm{Lz}$, where $\mathrm{Ct}$ was the last measured concentration and $\mathrm{Lz}$ was the slope of the terminal proportion of the plasma versus time concentration curve following natural logarithmic transmotion. The half-life $\left(\mathrm{t}_{1 / 2}\right)$, mean residence time (MRT), volume of distribution $(1 / \mathrm{kg})$ and clearance $(\mathrm{mL} / \mathrm{kg}$ per $\mathrm{min})$ were calculated using standard formulas.

\subsection{Organ bath myometrial study}

Ex vivo influence of carbetocin on equine myometrial muscles and comparison with oxytocin.

\subsubsection{Sample preparation}

Myometrial smooth muscle strips were obtained from 16 unmated cross-breed Nooitgedacht mares in estrus $(\mathrm{N}=5)$, diestrus $(\mathrm{N}=6)$, and anestrus $(\mathrm{N}=5)$ between the age of 3 and $10 \mathrm{yr}$ from a commercial abattoir (Krugersdorp Abattoir, Krugersdorp, South Africa). Stage of cycle was determined on examination of the ovaries and plasma progesterone concentrations (PPC). The presence of a corpus luteum and high progesterone concentration confirmed diestrus. A regressing corpus luteum, a low progesterone concentration, and a dominant follicle of more than $2 \mathrm{~cm}$ confirmed estrus. Inactive ovaries without a dominant follicle and a corpus luteum and low progesterone concentration confirmed anestrus.

\subsubsection{Sample collection}

A blood sample for plasma progesterone concentrations was collected in $5 \mathrm{~mL}$ heparin tubes during the slaughter of the animal, centrifuged, and the supernatant frozen for later analysis. The entire reproductive tract, including vagina, cervix, uterine body, uterine horns and both ovaries, were obtained immediately after slaughter. A 4-cm rectangular specimen was sectioned from the base of each uterine horn and placed into $4{ }^{\circ} \mathrm{C}$ cold Krebs-Henseleit solution (KHS) which was preoxygenated for 30 min with $95 \% \mathrm{O}_{2}$ and $5 \%$ $\mathrm{CO}_{2}$ in oxygen (carbogen) to reach a pH of 7.3 to 7.4. The KHS contained: $\mathrm{NaCl} 6.9 \mathrm{~g} / \mathrm{L} ; \mathrm{KCl} 0.35 \mathrm{~g} / \mathrm{L}$; $\mathrm{NaHCO}_{3} 2.09 \mathrm{~g} / \mathrm{L} ; \mathrm{MgSO}_{4} 0.14 \mathrm{~g} / \mathrm{L} ; \mathrm{KH}_{2} \mathrm{PO}_{4} 0.16 \mathrm{~g} / \mathrm{L}$; glucose $1.09 \mathrm{~g} / \mathrm{L} ; \mathrm{CaCl}_{2} \cdot 2 \mathrm{H}_{2} \mathrm{O} 0.28 \mathrm{~g} / \mathrm{L}$, and Napyruvate $0.22 \mathrm{~g} / \mathrm{L}$ and was made fresh before sample collection (all chemicals procured from Sigma-Aldrich (Pty), Ltd.). The samples were subsequently transported to the Faculty of Veterinary Science.
A uterine swab was taken from each mare and the smear examined for uterine pathology, such as the presence of neutrophils and bacteria indicating uterine inflammation. A full thickness uterine biopsy was taken from each mare for histopathology and evaluated according to Kenney [14]. This system takes into consideration inflammation and fibrosis of the endometrium and provides an estimation of the mare's ability to conceive and maintain a pregnancy until term. The uterus was graded: Grade I, IIA, IIB, or III. Mares with a Grade I have a more than $80 \%$ chance of conceiving and maintaining a pregnancy until term, whereas mares with a Grade III are expected to only have a $10 \%$ to $50 \%$ of conceiving and maintaining a pregnancy until term. Only mares without uterine pathology and an endometrial biopsy score of I and IIA were included in the study.

\subsubsection{Preparation of smooth muscle specimen}

After transportation to the laboratory, the 32 tissue samples were sectioned into $5 \times 20$-mm strips in warmed oxygenated KHS. All the prepared strips were full thickness and cut parallel to the longitudinal muscle fibers. The endometrium and any excess connective tissue were dissected apart from the muscle layers using a dissecting microscope.

\subsubsection{Tissue baths}

The 32 tissue samples were mounted in standard $100-\mathrm{mL}$ organ baths. Each bath was filled with $50 \mathrm{~mL}$ of KHS, maintained at $37^{\circ} \mathrm{C}$ and continuously bubbled with carbogen.

A force-displacement transducer attached to a chart recorder was used to evaluate the mechanical activity of the myometrium. Time from collection to tissue mounting was approximately 90 to $100 \mathrm{~min}$. Tissue strips were allowed to equilibrate for $30 \mathrm{~min}$ before tension being applied. Tissues were subsequently mounted under tension of $2 \times g$ [15], whereafter they were exposed to another $15 \mathrm{~min}$ of equilibration before initial stimulation.

Each muscle strip was exposed to four ascending concentration (Conc.) doses of oxytocin (0.086 [Conc. 1], 0.94 [Conc. 2], 9.5 [Conc. 3], and $52.3 \mathrm{ng} / \mathrm{mL}$ [Conc. 4]) and carbetocin (3.5 [Conc. 1], 38.5 [Conc. 2], 388.5 [Conc. 3], and $2138 \mathrm{ng} / \mathrm{mL}$ [Conc. 4]) (VTech Pharmacy, Midrand, South Africa) in a cumulative concentration-response protocol. Tissues were allowed $2 \mathrm{~min}$ to contract before ascension to the next dose. After the response to the additive last concentration was recorded, the compound was washed from the organ bath three times, before the subsequent assays 
were run. The tissues returned to their normal resting phase after the washes and the experiment was continued. Needed electrolytes were supplied in the buffer solution to avoid depletion of electrolytes. The tissues were given time to equilibrate between responses to return to no or initial contractility.

\subsubsection{Data analysis}

The amplitudes of the myometrial contractile activity were converted to \% response according the following equation: \% response $=$ amplitude achieved after exposure/highest amplitude achieved (all samples) multiplied by 100 . The maximum response $\left(\mathrm{E}_{\max }\right)$ and the concentration that produced $50 \%$ of the maximum effect $\left(\mathrm{EC}_{50}\right)$ were ascertained by curve fitting the dose response data to an $\mathrm{E}_{\max }$ equation (Kinetica 5, Thermo). $\mathrm{EC}_{50}$ is the concentration required to produce $50 \%$ of the response and can be used for comparison between drugs to the nature of the linear nature of pharmacodynamic (PD) graphs from $20 \%$ to $80 \%$. The $\mathrm{E}_{\max }$ is theoretically the concentration required to produce a maximum effect and is based on curve fitting. Due to the sigmoid nature of PD curves the $\mathrm{EC}_{50}$ is never related in a linear manner to $\mathrm{E}_{\max }$. The difference in response for the various cycles was evaluated using an ANOVA with Tukey Honestly Significant Difference (HSD) test and Bonferroni post hoc test.

Statistical analysis was performed with the statistical software SPSS19 (IBM South Africa, Sandton, South Africa). A Kolmogorov-Smirnov and Lilliefors table was used to assess the normality of distribution after various transformations. Because normality could not be demonstrated, differences per treatment for the different cycles were compared with a Kruskal-Wallis test and a $\mathrm{P}$ value of 0.05 post hoc comparison were made between the cycles using a Mann-Whitney test with the $\mathrm{P}$ value being set at 0.025 after Bonferroni correction. Differences between the different treatments per cycle were compared using a Mann-Whitney test at a P value of 0.05 .

\section{Results}

\subsection{Pharmacokinetic study}

The plasma versus time concentration profile obtained for oxytocin during the study is presented in Figure 1. The calculated pharmacokinetic parameters are presented in Table 1.

All the horses had baseline oxytocin concentrations of $0.009 \pm 0.004 \mathrm{ng} / \mathrm{mL}$. After administration oxytocin was characterized by a mean plasma concentration of $0.51 \pm 0.01 \mathrm{ng} / \mathrm{mL}$. The plasma concentration thereafter rapidly declined with the half-life of elimination of

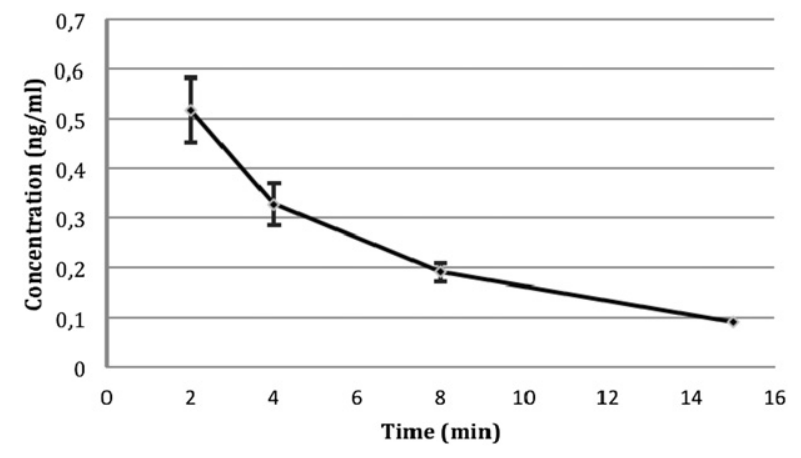

Fig. 1. Average plasma concentration versus time profile for horses after intravenous administration of 25 IU oxytocin (Fentocin, Virbac, Centurion, South Africa).

$5.89 \pm 0.699$ per min. The drug was also characterized by a low MRT of $7.708 \pm 1.15 \mathrm{~min}$.

\subsection{Organ bath myometrial study}

From the 16 mares used for the study, five mares were in estrus, six in diestrus, and five in anestrus. Uterine swabs showed no signs of infections, while all uterine biopsies were scored as Grade I or Grade IIA. From each of the 16 mares, two strips of uterine tissue, including longitudinal and circular muscle layers, were used for the study. Of the 32 samples only 14 (44\%) showed spontaneous uterine contractions. Five of the samples showing spontaneous contractions were obtained from mares in estrus, two samples from mares in diestrus, and seven samples from mares in anestrus.

\subsection{1. $E C_{50}$ values for oxytocin and carbetocin}

Figure 2 shows the $\mathrm{EC}_{50}$ values $(\mathrm{ng} / \mathrm{mL})$ for oxytocin and carbetocin for mares in estrus, diestrus, and anestrus. Mean $\pm \mathrm{SD}$ for oxytocin $\mathrm{EC}_{50}$ values were $4.57 \pm 5,3.12 \pm 4.47,0.45 \pm 0.92 \mathrm{ng} / \mathrm{mL}$ for estrous, diestrous, and anestrous mares. Mean \pm SD for carbetocin $\mathrm{EC}_{50}$ values were $6.95 \pm 6.73,10.51 \pm 13.68$, $3.47 \pm 4.65 \mathrm{ng} / \mathrm{mL}$ for estrous, diestrous, and anestrous mares.

No significant difference could be observed between any of the estrous cycle phases for carbetocin ( $\mathrm{P}=$ $0.79)$. For oxytocin a significant difference was present between stages $(\mathrm{P}=0.007)$ : estrus and anestrus $(\mathrm{P}=$ $0.008)$, and diestrus and anestrus $(P=0.009)$, while no significant difference was present between estrus and diestrus $(\mathrm{P}=0.425)$. Comparison between oxytocin and carbetocin during the different cycle stages revealed a significant difference for anestrus $(\mathrm{P}=0.031)$ but no significant difference for estrus and diestrus.

Figure 3 shows the effect of oxytocin on equine myometrial tissue ex vivo at different stages of the 
Table 1

Plasma pharmacokinetic parameter for oxytocin following a single intravenous injection of 25 IU to six Nooitgedacht mares.

\begin{tabular}{|c|c|c|c|c|c|c|c|c|c|}
\hline Animal & $\begin{array}{c}\mathrm{AUC}_{\text {last }} \\
(\mathrm{ng} / \mathrm{mL} \times \min )\end{array}$ & $\begin{array}{c}\mathrm{AUC}_{\mathrm{inf}} \\
(\mathrm{ng} / \mathrm{mL} \times \mathrm{min})\end{array}$ & $\begin{array}{c}\mathrm{Lz} \\
(\mathrm{L} / \mathrm{min})\end{array}$ & $\begin{array}{c}\mathrm{AUMC}_{\text {last }} \\
\left(\mathrm{ng} / \mathrm{mL} \text { per } \mathrm{min}^{2}\right)\end{array}$ & $\mathrm{t}_{1 / 2}(\min )$ & MRT (min) & $\begin{array}{c}\text { Clearance } \\
(\mathrm{L} / \mathrm{min} \times \mathrm{kg})\end{array}$ & Vss (L/kg) & $\mathrm{Vz}(\mathrm{L} / \mathrm{kg})$ \\
\hline 1 & 5080 & 6020 & 0.12 & 24300 & 5.84 & 7.68 & 9.14 & 70.25 & 77.07 \\
\hline 2 & 3550 & 4430 & 0.10 & 18400 & 6.44 & 8.97 & 12.40 & 111.24 & 115.27 \\
\hline 3 & 4540 & 5340 & 0.12 & 21500 & 5.77 & 7.55 & 10.29 & 77.70 & 85.70 \\
\hline 4 & 3690 & 4640 & 0.10 & 19700 & 6.63 & 9.26 & 11.83 & 109.61 & 113.25 \\
\hline 5 & 3710 & 4320 & 0.11 & 15400 & 6.02 & 6.94 & 12.70 & 88.25 & 110.44 \\
\hline 6 & 3600 & 4010 & 0.14 & 16100 & 4.64 & 6.26 & 13.70 & 85.78 & 91.81 \\
\hline Mean & 4030 & 4790 & 0.11 & 19200 & 5.89 & 7.78 & 11.67 & 90.47 & 98.92 \\
\hline Median & 3700 & 4540 & 0.11 & 19000 & 5.93 & 7.62 & 12.11 & 87.02 & 101.13 \\
\hline SD & 630 & 745 & 0.01 & 3350 & 0.69 & 1.15 & 1.67 & 16.71 & 16.17 \\
\hline$\% \mathrm{CV}$ & 15.63 & 15.55 & 9.09 & 17.44 & 11.71 & 14.78 & 14.31 & 18.47 & 16.89 \\
\hline
\end{tabular}

$\mathrm{AUC}_{\text {inf }}$, area under the concentration-time curve extrapolated to infinity; $\mathrm{AUC}_{\text {last }}$, area under the concentration-time curve to the last plasma sampling time; $\mathrm{AUMC}_{\text {last }}$, area under the moment curve to the last sampling time; Lz, slope of the curve (slope of the linear regression of the $\log$-transformed concentration-time); MRT, mean residence time; $\mathrm{t}_{1 / 2}$, half-life of elimination; Vss, volume of distribution at steady state; Vz, volume of distribution at the terminal stage.

estrous cycle. A weak relative response of estrous myometrial tissue can be observed for Conc. 1 and 2 . Thereafter the relative response increases for Conc. 3 and Conc. 4 in a dose-dependent fashion. During diestrus, a similar myometrial response can be observed but with an overall stronger relative response of the myometrial tissue to oxytocin, compared with estrous myometrial tissue. During anestrus, a dose-dependent increase in response can be observed with increasing concentrations, up to Conc. 3 whereafter the relative response of the myometrial tissue stays the same or starts to decline with Conc. 4 indicating that the maximum achievable effect has been reached. The mean relative response of oxytocin shows a steady increase with increasing drug concentrations. Figure 4 shows the effect of carbetocin on equine myometrial tissue ex vivo at different stages of the estrous cycle. The relative

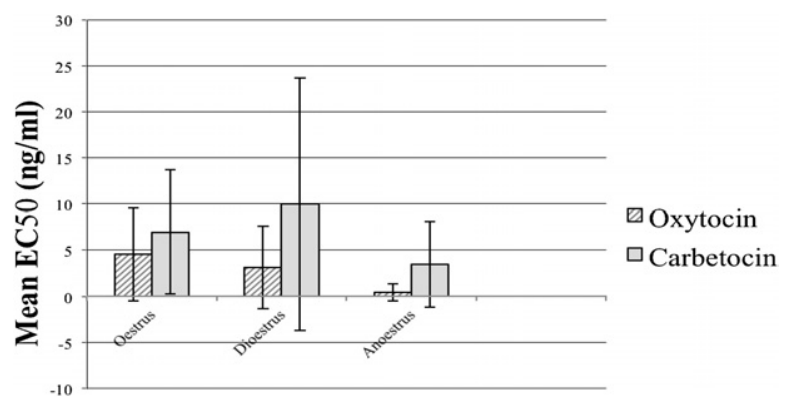

Fig. 2. Effect of oxytocin and carbetocin on estrous $(\mathrm{N}=10)$, diestrous $(\mathrm{N}=12)$, and anestrous $(\mathrm{N}=10)$ myometrial tissue described as mean concentration that produced $50 \%$ of the maximum effect $\left(\mathrm{EC}_{50}\right)(\mathrm{ng} / \mathrm{mL} ; \pm \mathrm{SD})$. Significant difference between stages only for oxytocin: estrus and anestrus $(\mathrm{P}=0.008)$, diestrus and anestrus $(\mathrm{P}=0.009)$. response of estrous myometrial tissue to carbetocin is weak for Conc. 1, stronger for Conc. 2, 3, and 4, but with no dose-dependent increase for these concentrations. A stronger relative response to carbetocin can be observed for diestrous and anestrous myometrial tissue compared with estrous tissue, especially in response to Conc. 1.

The mean relative response of carbetocin shows a dose-dependent increase up to Conc. 2, whereafter the effect plateaus.

\section{Discussion}

To determine the intercyclic effect of carbetocin and oxytocin, the effect of the drugs was evaluated through pharmacokinetic and pharmacodynamic studies. The effects of both drugs in organ baths were evaluated. To determine the validity of the results, the $\mathrm{EC}_{50}$ 's ob-

\section{Oxytocin}

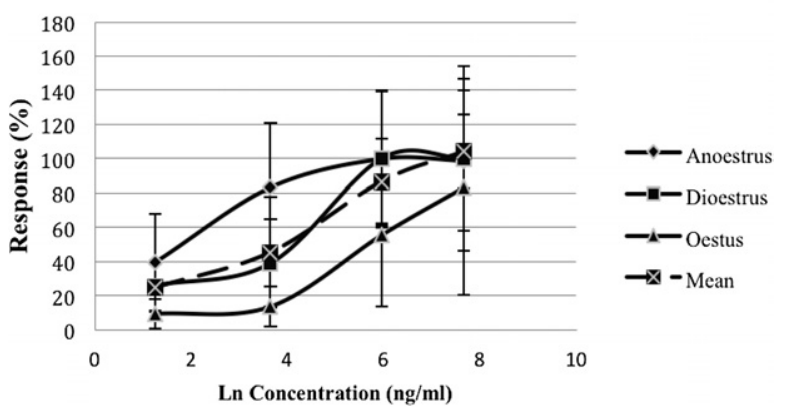

Fig. 3. Effect of cycle stage on myometrial response to oxytocin stimulation ex vivo (estrus $\mathrm{N}=10$, diestrus $\mathrm{N}=12$, anestrus $\mathrm{N}=$ $10, \pm \mathrm{SD})$. 


\section{Carbetocin}

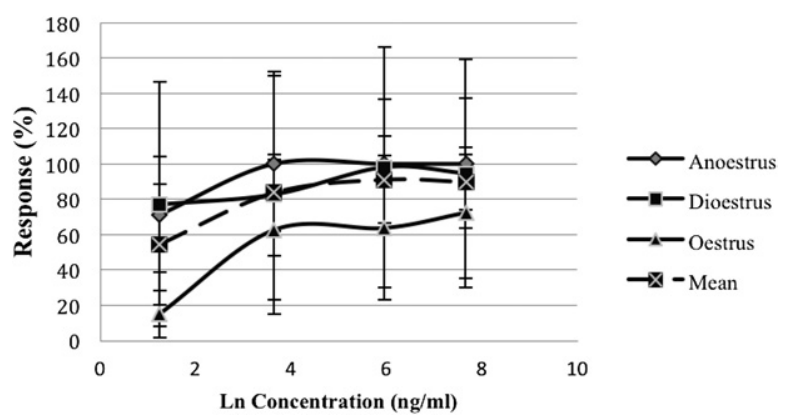

Fig. 4. Effect of cycle stage on myometrial response to carbetocin stimulation ex vivo (estrus $\mathrm{N}=10$, diestrus $\mathrm{N}=12$, anestrus $\mathrm{N}=$ $10, \pm \mathrm{SD})$.

tained were compared with estimated effective plasma concentration.

Because the complete pharmacokinetic profile for oxytocin was unknown the first part of modeling was to establish the pharmacokinetics of oxytocin. For the current study the half-life of oxytocin in cycling, nonpregnant mares was determined to be $5.89 \mathrm{~min}$, which differed minimally from the half-life of $6.8 \mathrm{~min}$ reported by Paccamonti, et al. [16]. The difference in the half-life of the two studies most likely results from the different animals used in the two studies (Warmblood mares vs. Nooitgedacht mares) as the difference in body weight and metabolic capacity might affect the clearance rate and the half-life of the drug. This result is supported by other pharmacokinetic studies on oxytocin in farm animals, where a half-life of $22.3 \mathrm{~min}$ was reported in goats while the half-life in cattle, from various studies, was approximately 7 to $9 \mathrm{~min}$ [17-20]. As can be seen from this study, there is an inverse proportional relationship between body weight and the half-life of response (i.e., the smaller animal being the goat having the longer half-life). Another interesting feature of oxytocin is that its metabolism appears to be largely extrahepatic. Mitchell and coworkers found that rat uterine tissue contains peptidase activity which degrades, metabolizes, and thus inactivates oxytocin. They speculated that this mechanism could be important in regulating the metabolism of oxytocin during parturition [21].

As expected oxytocin was characterized by a low MRT and a high mean volume of distribution (Vd). Because MRT represented approximately $63 \%$ of total time any drug spends in the body, the small value obtained for this study was clearly related to the rapid half-life of the drug. As an estimate the MRT was inversely proportional to the elimination constant. The same principle may be applied to the $\mathrm{Vd}$. The $\mathrm{Vd}$ was determined from the dose being administered against the maximum plasma concentration after intravenous administration. Because the maximum concentration achievable was clearly related to half-life, the rapid elimination did result in a falsely elevated Vd. However, another factor that most likely contributed to the high Vd was the ability of oxytocin to be highly tissuebound and metabolized in the biophase where it was active [21] at the level of oxytocin receptor.

To determine the validity of the results achieved from the ex vivo study, the results were evaluated using pharmacokinetic-pharmacodynamic modeling.

The use of ex vivo techniques to study uterine contractility permits the evaluation of specific contractile responses in tissues obtained from animals of precisely known in vivo functional status in the absence of potentially confounding interactions that might occur in vivo [22]. Ex vivo studies on smooth muscle strips in organ baths have served as an alternative for investigations of myometrial activity. The ex vivo assessment of the contractility of the smooth muscle layer of the uterus in the mare may serve as a more precise and accurate measurement for understanding the influence and interaction of endogenous and exogenous drugs under in vivo conditions [15,23]. For this study, the effect of the selected agonists on the myometrium alone was determined, as this tissue contains the receptor series involved with contractility.

During the initial part of the experiment, spontaneous contraction of equine myometrial tissue could be observed in only 14 out 32 samples (44\%). This was markedly different from a study by Hirsbrunner and coworkers [15], who were able to demonstrate spontaneous myometrial contractions of all estrous and diestrous circular and longitudinal myometrial tissue samples, whereas Rigby and coworkers [23] were "seldom" able to, while Ousey et al. [24] were not able to demonstrate any spontaneous myometrial contractions. This tends to suggest that the response of the myometrium is dependent on a number of factors, such as survivability of tissue ex vivo, number of active receptors, muscle activity, and individual variation.

The $\mathrm{EC}_{50}$ (amount of drug necessary to achieve 50\% of maximal contraction) was found to be highest in estrous tissues, lower in diestrous tissues, and lowest in anestrous myometrial tissues after oxytocin administration. Although the $\mathrm{EC}_{50}$, due to the sigmoid nature of OD curves, is not related in a linear manner to $\mathrm{E}_{\max }$, the effect on estrous tissue is unexpected as the results do not follow clinical responses for the drug. The high 
$\mathrm{EC}_{50}$ of estrous tissue suggests that an increased amount of oxytocin is needed to cause a response of the myometrium. Expected was that, due to a high concentration of oxytocin receptors within the myometrium during estrus, a decreased amount of oxytocin is needed to result in a myometrial response, as suggested by literature [27]. One explanation may involve the rapid metabolism at the level of the endometrium. This mechanism was not considered important for this study, as the endometrium was removed before tissue incubation. A second explanation may involve the concentration of active receptors at the level of the muscles. In studies by Tetzke et al. [25], it was clearly demonstrated that the myometrium receptivity for oxytocin depends on the cycle stage. Further studies by Stull and Evans [26] and Sharp et al. [27] have demonstrated that the oxytocin receptors are present to a greater extent in the myometrium than in the endometrium of nonpregnant and pregnant mares. Receptor numbers have also been shown to differ within the estrous cycle itself as the highest concentration of receptors can be found during early estrus (Day 14-17), compared with late estrus (Day 18 to 0), and diestrus (Day 1-13) [27]. The estrous tissue used in this study had been collected from mares in advanced estrus (Day 18 to 0) during which the receptor number has found to be lower than in early estrus, increasing the $\mathrm{EC}_{50}$ to some degree. It raises the question if a higher receptor concentration will result in a higher response, and how will this be evident in the animal in vivo? During an ex vivo study no inhibitory systems are in place as would be in vivo, which might influence the results. No literature could be found with regard to the response of myometrial tissue to oxytocin during anestrus. It is surprising that anestrous myometrial tissue should have a significantly lower $\mathrm{EC}_{50}$ than estrous and diestrous tissue and thus a higher response to oxytocin, assumingly due to a higher oxytocin receptor concentration. These results can currently not be explained and need further investigation.

In contrast, myometrial contractility in response to carbetocin did not appear to be affected by the stage of the cycle. The reason for the lack of a stage-related response by carbetocin is more difficult to explain. One reason for the effect seen may be due to a difference in receptor binding between oxytocin and carbetocin. The first receptor mechanism results from the direct stimulation of the myometrium via a vasopressin receptor with subsequent activation of a calcium-controlling second messenger system [28]. The second receptor mechanism relies on the stimulation of oxytocin receptors in the endometrium and myometrium with subse- quent release of $\mathrm{PGF}_{2 \alpha}$ and its related stimulation of uterine contractions and luteolysis [28]. Of these two receptor series the oxytocin receptor is cyclic (as mention above) in their concentration while the vasopressin receptor remains at a constant level [28]. In a study by Engstrøm et al. [28] it was further demonstrated that oxytocin had poor affinity for the vasopressin receptor while carbetocin had affinity for both receptor series. This would therefore explain the differences evident, i.e., the effect of oxytocin being cyclic due to cyclic activation of the receptor while carbetocin is able to produce a constant effect due to the constant concentration and presence of the vasopressin receptors system [28].

Based on the pharmacokinetic profile for oxytocin and the known effective duration of $6.8 \mathrm{~min}$ for the nonpregnant mare, the effective plasma concentration is estimated to be $0.25 \mathrm{ng} / \mathrm{mL}$. This was similar to the concentration achieved for the organ bath study where the lowest $\mathrm{EC}_{50}$ was calculated at $0.45 \mathrm{ng} / \mathrm{mL}$ for anestrous mares. When the same trend is applied to the published carbetocin pharmacokinetic information, and the effective duration of $17 \mathrm{~min}$, the effective plasma concentration was estimated to be $3 \mathrm{ng} / \mathrm{mL}$. This was once again familiar to the lowest $\mathrm{EC}_{50}$ of $3.47 \mathrm{ng} / \mathrm{mL}$ in anestrous mares. This therefore tends to suggest that the organ bath concentrations are relevant to the adult horse.

\subsection{Conclusions}

The results suggest that the effect of oxytocin on equine myometrial tissue is higher during diestrus, and surprisingly anestrus, than during estrus, whereas the effect of carbetocin seems to be the same independent of the stage of estrous cycle. An advantage of carbetocin is its longer half-life (17 min) over the half-life of oxytocin $(6 \mathrm{~min})$ in the mare.

These results might be useful in the treatment of uterine pathology, such as advanced stages of PMIE, pyometra, as well as for induction or enhancement of myometrial contractions during parturition.

\section{Acknowledgments}

The authors thank Prof. Botha and the Section of Pharmacology, Faculty of Veterinary Science, South Africa, for the usage of the laboratory facilities, and Stefanie Münscher for assistance with the running of the oxytocin assay, as well as V-Tech, South Africa, for the sponsorship of the drugs used in the study.

The authors declare no conflicts of interest. 


\section{References}

[1] Gündüz MC, Kasikci G, Kaya HH. The effect of oxytocin and PGF2[alpha] on the uterine involution and pregnancy rates in postpartum Arabian mares. Anim Reprod Sci 2008;104:25763.

[2] Troedsson MH. Uterine clearance and resistance to persistent endometritis in the mare. Theriogenology 1999;52:461-71.

[3] Nikolakopoulos E, Watson ED. Can uterine contractile activity be evaluated by transrectal ultrasonography? Equine reproduction; III. Proceedings of the Eighth International Symposium on Equine Reproduction, Fort Collins, 2002. Theriogenology 2002; 58:483-86.

[4] Evans MJ, Hamer JM, Gason LM, Graham CS, Asbury AC, Irvine $\mathrm{CH}$. Clearance of bacteria and non-antigenic markers following intra-uterine inoculation into maiden mares: effect of steroid hormone environment. Theriogenology 1986;26:37-50.

[5] Blanchard TL, Varner DD, Brinsko SP, Quirk K, Rugila JN, Boehnke L. Effects of ecbolic agents on measurements of uterine involution in the mare. Theriogenology 1992;36:559-71.

[6] Jain TL, Saade GR, Garfield RE. Uterine contraction. Encyclopedia of reproduction, Volume 4, Knobil E, Neill JD (Eds.), New York: Academic Press, 1999, pp. 932-42.

[7] Schramme AR, Pinto CR, Davis JL, Whitacre MD, Whisnant CS. Pharmacokinetics of carbetocin, a long-acting oxytocin analogue, following intravenous administration in horses. Theriogenology 2007;68:517-8.

[8] Ley WB, Purswell BJ, Bowen JM. The effects of prostalene and alfaprostol as uterine myotonics, and the effect on postpartum pregnancy rate in the mare following daily treatment with prostalene. Theriogenology 1988;29:1113-21.

[9] Bajcsy AC, Szenci O, van der Weijden GC, Doornenbal A, Maassen F, Bartyik J, et al. The effect of a single oxytocin or carbetocin treatment on uterine contractility in early postpartum dairy cows. Theriogenology 2006;65:400-14.

[10] Ngan L, Keong W, Martins R. Carbetocin versus a combination of oxytocin and ergometrine in control of postpartum blood loss. Int J Gynecol Obstet 2007;97:152-3.

[11] Boucher M, Nimrod C, Tawagi G. Carbetocin im injection vs oxytocin iv infusion for prevention of postpartum hemorrhage in women at risk following vaginal delivery. Am J Obstet Gynecol 2001; Abstract:494.

[12] Van Dongen PWJ, Verbruggen MM, de Groot ANJA, van Roosmalen J, Sporken JMJ, Schulz M. Ascending dose tolerance study of intramuscular carbetocin administered after normal vaginal birth. Eur J Obstet Gynecol Reprod Biol 1998;77: 181-7.

[13] Bernhard A, Schulz J, Gutjahr S, Eulenberger K. Indications for a long acting oxytocin in veterinary practice. Tierärztl Umsch 1993;48:446-53.
[14] Kenney RM. Cyclic and pathologic changes of the mare endometrium as detected by biopsy, with a note on early embryonic death. J Am Vet Med Assoc 1978;172:241-62.

[15] Hirsbrunner G, Reist M, Couto SS, Steiner A, Snyder J, vanLeeuwen E, et al. An in vitro study on spontaneous myometrial contractility in the mare during estrus and diestrus. Theriogenology 2006;65:517-27.

[16] Paccamonti DL, Pycock JF, Taverne MAM, Bevers M, Van Der Weijden GC, Gutjahr S, et al. PGFM response to exogenous oxytocin and determination of the half-life of oxytocin in nonpregnant mares. Equine Vet J 1999;31:285-8.

[17] Homeida AM, Cooke RG. Biological half-life of oxytocin in the goat. Res Vet Sci 1984;37:364-5.

[18] Gorewit RC. Method for determining oxytocin concentrations in unextracted sera; characterization in lactating cattle. Proc Soc Exp Biol Med 1979;160:80-7.

[19] Schams D, Schmidt-Polex B, Kruse V. Oxytocin determination by radioimmunoassay in cattle. I. Method and preliminary physiological data. Acta Endocrinol 1979;92:258-70.

[20] Wachs EA, Gorewit RC, Currie WB. Half-life, clearance and production rate for oxytocin in cattle during lactation and mammary involution. Domest Anim Endocrinol 1984;1:121-40.

[21] Mitchell BF, Fang X, Wong S. Metabolism of oxytocin in rat uterus and placenta in late gestation. Biol Reprod 1997;57:80712.

[22] Baguma-Nibasheka M, Wentworth RA, Green LR, Jenkins SL, Nathanielsz PW. Differences in the in vitro sensitivity of ovine myometrium and mesometrium to oxytocin and prostaglandins E2 and F2alpha. Biol Reprod 1998;58:73-8.

[23] Rigby SL, Barhoumi R, Burghardt RC, Colleran P, Thompson JA, Varner DD, et al. Mares with delayed uterine clearance have an intrinsic defect in myometrial function. Biol Reprod 2001; 65:740-7.

[24] Ousey JC, Freestone N, Fowden AL, Mason WT, Rossdale PD. The effects of oxytocin and progestagens on myometrial contractility in vitro during equine pregnancy. J Reprod Fertil Suppl 2000:681-91.

[25] Tetzke TA, Ismail S, Mikuckis G, Evans JW. Patterns of oxytocin secretion during the oestrous cycle of the mare. J Reprod Fertil Suppl 1987:245-52.

[26] Stull CL, Evans JW. Oxytocin binding in the uterus of the cyclic mare. J Equine Vet Sci 1986;6:114-19.

[27] Sharp DC, Thatcher MJ, Salute ME, Fuchs AR. Relationship between endometrial oxytocin receptors and oxytocin-induced prostaglandin F2 alpha release during the oestrous cycle and early pregnancy in pony mares. J Reprod Fertil 1997;109:13744.

[28] Engstrøm T, Barth T, Melin P, Vilhardt H. Oxytocin receptor binding and uterotonic activity of carbetocin and its metabolites following enzymatic degradation. Eur J Pharmacol 1998;355: 203-10. 